\title{
ORGANISATIONAL CULTURE CHARACTERISATION OF CONSTRUCTION FIRMS IN NIGERIA
}

\author{
Adebisi Abosede Bamgbade ${ }^{1 *}$, Richard Ajayi Jimoh ${ }^{1}$, Luqman Oyekunle Oyewobi ${ }^{2}$, Maroof \\ Anifowose $^{2}$ \\ ${ }^{1}$ Department of Building, School of Environmental Technology, Federal University of Technology \\ Minna, Niger state, Nigeria \\ ${ }^{2}$ Department of Quantity Surveying, School of Environmental Technology, Federal University of \\ Technology Minna, Niger state, Nigeria
}

(Received: August 2020 / Revised: September 2020 / Accepted: December 2020)

\begin{abstract}
Organisational culture characterisation is indispensable for aspiring organisations that want to measure up with the contemporary business trend in terms of performance. This paper aims to determine the organisational culture characterisation of construction firms in Nigeria to improve the organisational culture power to drive organisational performance of the firms. Thus, the objectives are to enumerate the factors that contribute to the organisational culture capability and to determine the organisational culture characterisation of construction firms in Nigeria. A quantitative method was adopted for this research in which 113 questionnaires from a sample size of 254 disseminated informed by purposive random sampling technique, were used to draw the data from the respondents who are predominantly construction workers. The analysis of the data was done using factor analysis, k-mean analysis, and a one-way ANOVA. The results reveal that there is the presence of three distinct organisational culture clusters in the construction firms in Nigeria. The results also disclosed that family and work policy should be inculcated into the organisational culture and held in regard if performance is inevitable. The study concluded that organisational culture is a vital aspect of construction firms and each firm should improve on their culture to better their organisational performances. It is recommended that family and work policy should be given preference in the organisation, also supervisors should be trained in relevant skills that will aid their commitment to their workforce diversity.
\end{abstract}

Keywords: Characterisation; Cultural Diversity; Performance; Organisational Culture; Culture Types

\section{INTRODUCTION}

Organisational culture has a great influence on firms as in some cases it has taken some time to be developed even though it's constantly being improved upon by some resulting in either their strength or weaknesses. There are two basics organisational culture types; the strong and the weak culture (Agboola, 2011; Gibson et al., 2012; McShane \& Steen, 2015). The work processes they put in place signify why some firms are stronger and more productive than the others.

\footnotetext{
*Corresponding author's email: bisbam@gmail.com, Tel. +2348166702508
}

DOI: https://doi.org/10.32783/csid-jid.v3i2.150 
Organisational culture has been mirrored through the variable of teamwork (Khoshtale, 2016), cultural diversity (Khoshtale, 2016; Saxena, 2014), diversity management (Sezerel \& Tonus, 2016) and organisational performance (Hogan \& Coote, 2014).

Organisational culture has only being related to one or two of the aforementioned variables in a single study (Hogan \& Coote, 2014), but this study is unique in that organisational culture is being related to all the aforementioned variables with the view of discovering its potency through them to promote the organisational performance of construction firms in Nigeria.

The performance outcome of organisations speaks volumes of the firm's abilities, capacity, strength, and continuity (Agboola, 2011). And this goes a long way in determining the sustainability of the firm's continuance in business. Construction firms in Nigeria have been opined poor in organisational performance as a result of various factors in which cultural issues have been established as part of the problem (Nikpour, 2017). Of very recent little focus has been concentrated on the softer aspect culture on the discovering that it reflects in the human resource on which hang all other aspects of construction. On the premise of poor performance experiences within the construction firms in Nigeria, it is noteworthy to establish the organisational culture characterisation of the construction firms in Nigeria as a means of creating awareness on the importance of culture on construction sites to improve on their organisational culture strength and performance.

This paper aimed at determining the organisational culture characterisation of construction firms in Nigeria to improve its power to drive the performance of the firms. To achieve this aim, the objectives are to:

1. Enumerate the factors that contribute to the organisational culture capability

2. Determine the organisational culture characterisation of construction firms in Nigeria.

Culture has become a business thing in this century for firms that want to stay longer in business especially when in collaboration with other firms and international business alliance (Horwitz, 2005; Olsen \& Martins, 2012; Syed \& Kramar, 2009). The liquidation of many construction firms in Nigeria is obvious as well as at an alarming rate although some others are still thriving in business. However, some are still struggling to survive (Hogan \& Coote, 2014). It is therefore imperative to investigate how those succeeding firms were able to survive in the construction business. Also, works that focus on the organisational characterisation of construction firms are limited, and these informed this research (Teräväinen et al., 2018). This research covered construction firms in Abuja and Lagos, Nigeria. The foreign and also indigenous construction firms formed the basis of the research parameters used in this paper.

\section{LITERATURE REVIEW}

\subsection{Organisational Culture Perspective of Construction Firms}

The construction industry involves an ample number of workers on construction sites employed for the execution of projects, which is expected to conform to the key performance indicators in the local and global economy. This was as rightly opined by Preeti et al. (2014) that construction final products influence the growth of the nation. There are variances in the organisational culture set up of every organisation. The differences can be traced to the mindset of the founders and their leadership styles which are being disseminated throughout the system (Gibson et al., 2012).

Essentially, the effect and differences in culture usually come to the limelight when the construction firms are in collaborations together in project execution (Shore \& Cross, 2005). It is essential to know that within the construction organisations are varying cultures that firms 
contend with throughout the construction activities and the existence of the firm. Akinyemi et al. (2016) observed that construction firms conduct project activities on a big, complex platform which nonetheless, gives rise to several challenges on sites. Furthermore, cases of poorly built buildings have resulted in the loss of precious lives, huge amounts of money, reputation, license, as well as the probe and profound consequences to the company (Akinyemi et al., 2016). Therefore, construction work must be done to meet the highest standard of work (Ofori, 2015). This succinctly connotes that organisations have to invest in their workforce diversity to realise this high standard (Loosemore et al., 2012).

\subsection{Factors That Contribute to The Organisational Culture Capability}

Organisational culture no doubt is the core by which values are enacted and transmitted to the human resources. It has been established that elements such as leadership, teamwork, behaviour, and attitudes of employees as a result of cultural diversity traits, management; diversity management, and organisational performance which is a reflection of the outcome of the processes by which work is carried out, influences the organisational culture capability of every firm such as construction organisation (Chartered Management Institute, 2015).

\subsection{Organisational Culture Characterisation of Construction Firms}

Enyioko (2017) stated that variation in values between cultures and countries can be analysed via characterisation into different levels. This was in consonant with Starcher (1997) in Enyioko (2017), who in a business context defined ethical development in a particular structure irrespective of culture.

\subsubsection{Strong Organisational Culture}

A strong organisational culture would align the employee along with the mutual corporate culture which would reflect on their attitude to work, and behaviour to one another. When a firm can actualise this, the firm is said to have a strong organisational culture (Agboola, 2011; Gibson et al., 2012). This is in line with Loosemore et al. (2012) and Hitt et al. (2010), who asserted that good management of cultural diversity is required if the organisation would succeed in businesses that involved diverse workers. In this case employees' culture is very close to their organisational culture values.

\subsubsection{Weak organisational culture characterisation}

On the other hand, weak organisational culture arises from the inability of the arbiter to align the members of their firms to the core values of the firms (Agboola, 2011; Hitt et al., 2010). In such cases only a few such as the leadership, executives, accept and support the core values of the firm while the other people in the workforce do not key into the corporate culture. Consequently, their attitude and behaviour towards their work and others are not being influenced by the culture within the organisation. In this scenario employees' culture is very far from their organisational culture values.

\subsection{Clustering of Organisational Culture}

Many authors such as Sorge and Hofstede (1983), Olsen and Martins (2012) had developed typologies, models to describe organisational culture. However, for a study that wants to establish construction organisational culture characterisation, the distinction of organisational culture by strength type is necessary. The two distinct types of organisational culture in literature are strong culture, and weak culture (Elangovan \& Jayashree, 2013; Maseko, 2017).

\subsection{Moderate Culture}

Looking at the culture model of Cameron and Quinn (2011), they described a culture in four strands; adhocracy, clan, market, and hierarchy. Dwelling on the last concept hierarchy culture 
- a control-oriented culture in which key values are built on efficiency and close adherence to rules and regulations (Sanz-Valle et al., 2011). Given that there is a degree of hierarchy culture which is high, low, and moderate (SHRM, 2020) then we can also say that there is a possibility of moderate organisational culture strength within the organisations. Agreeably, (Angela, et al., 2017) stated that there will always exist a middle ground in deep-thinking discussion context.

Moderate organisational culture is in between the strong culture and weak culture. In this case, employees' culture is neither very close nor very far to their organisational culture values.

\subsection{Theoretical Framework}

Some theoreticians considered culture based on objects, facts, and people which has an element of mutual conditioning of the mind discriminating the affiliates of any classification of persons from another (Hofstede, 1993).

It is essential to note that within teamwork are diverse cultures (Olsen \& Martins, 2012). Furthermore, for construction firms to tap considerably from the diversities within their teamwork for successful performances, the organisations should be at the centre of leveraging the subcultures within their teamwork and workforce through their organisational culture for successful performances. The reason being that the cultural diversities feature such as cognitive, education, gender, family, belief, the cultural background can cause conflicts within the teamwork as workers interact together. This is in line with Loosemore et al. (2012), who opined that effective management of cultural diversity is needed to achieve a better working relationship and work success.

This study adopted the contingency theory. This theory argues that there is no right way to organise as well as make decisions about a corporation. It can be described simply as the ' it depends' approach, while a large number of variables in the workplace can influence decisions (Brett et al., 2006).

Going by Olsen and Martins (2012) cultural diversity management model, they built up a model in which they relate cultural diversities, group, and performance together. They observed that with a good diversity management style that presents a diverse method of value types and acculturation strategies the conflicts that exist within the workgroup can be assuaged and good performance inevitable. However, this paper further looked at the intrinsic within the teamwork. The conceptual framework is thus as displayed in Figure 1.

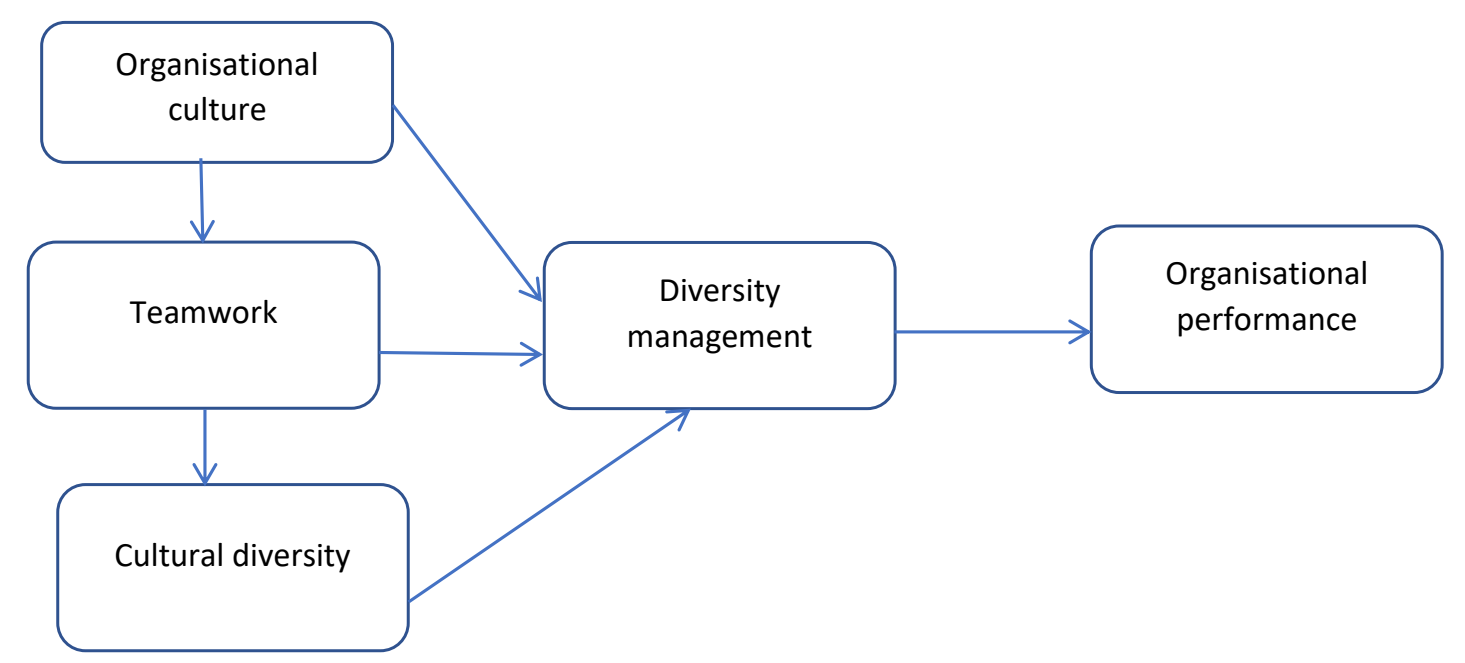

Figure 1. Conceptual framework 


\section{RESEARCH METHODOLOGY}

This study objects to bring to fore factors that contribute to the organisational culture capability of construction firms in Nigeria. Furthermore, we intents to determine the organisational culture characterisation of construction firms in Nigeria.

To actualize these purposes, we carried out a mixed-method study in some selected construction firms in Lagos and Abuja. Mixed method research has been continuously used in the field of construction management (Oyewobi, 2014) which this study falls into because the two strands of research it contains can leverage on one another strength thereby bringing out a satisfying result compared to when it is only quantitative or qualitative research. An earlier study by Ankrah (2007) had implored the use of mixed-method study in construction management research since it is lacking. Furthermore, the result from one strand of research can become the basis of drawing out questions for the other strand of research to get at intrinsic occurrence/situation. However, it is noteworthy to state here that the data we collected for this study was via the quantitative aspect of the mixed method which serves as the main technique for this aspect of work. We measured five variables in this study as presented in Table 1.

Table 1. Type and source of variables used in the study

\begin{tabular}{|c|c|c|c|}
\hline Constructs & Measured variables & Authors & Type of variable \\
\hline Organisational culture & $\begin{array}{l}\text { Leadership and } \\
\text { communication } \\
\text { Employees'value }\end{array}$ & $\begin{array}{l}\text { Loosemore et al. (2012) } \\
\text { Schwartz (2012) }\end{array}$ & $\begin{array}{l}\text { Independent } \\
\text { variable }\end{array}$ \\
\hline Teamwork & Teamwork variables & $\begin{array}{l}\text { High performing systems Inc. } \\
2009\end{array}$ & $\begin{array}{l}\text { Independent } \\
\text { variable }\end{array}$ \\
\hline Cultural diversity & $\begin{array}{l}\text { Demographic diversities } \\
\text { Socio-cognitive diversities } \\
\text { Organisational diversities }\end{array}$ & $\begin{array}{l}\text { Rijamampinina and Carmichael } \\
\text { (2005 }\end{array}$ & $\begin{array}{l}\text { Independent } \\
\text { variable }\end{array}$ \\
\hline Diversity management & $\begin{array}{l}\text { Accountability practices } \\
\text { Development practices } \\
\text { Recruitment practices }\end{array}$ & Kreitner and Kinichi (2004) & $\begin{array}{l}\text { Independent } \\
\text { variable }\end{array}$ \\
\hline $\begin{array}{l}\text { Organisational } \\
\text { performance }\end{array}$ & $\begin{array}{l}\text { Employee turnover } \\
\text { Employee retention } \\
\text { Productivity } \\
\text { Work quality } \\
\text { Creativity and innovations } \\
\text { Problem-solving } \\
\text { Workgroup cohesiveness } \\
\text { Workgroup communication } \\
\text { Overall firm performance }\end{array}$ & $\begin{array}{l}\text { David et al. (2007) } \\
\text { Sheridan (1992) } \\
\text { Waiganjo et al. (2012) }\end{array}$ & $\begin{array}{l}\text { Dependent } \\
\text { variable }\end{array}$ \\
\hline
\end{tabular}

Explicitly, in the year 2019, we carried out fieldwork with the staff of indigenous, foreign construction firms in Lagos, and Abuja that have their organisation registered with the Corporate Affairs Commission (CAC). What informed the selection of these firms was based on purposive random sampling technique (Flyvbjerg, 2006). The selection of companies, however, was achieved through a v-connect directory (www.vconnect.com) that have a wider range of lists of construction firms in Nigeria.

From the v.connect directory, a population size of 3,888 construction firms from the two selected areas (Lagos and Abuja) was established. The sample size was determined from Bartlett et al. (2001) table for determining sample size for continuous and categorical data. The 
population size close to 3,888 on the table was 4000 which corresponded to a sample size of 254 for categorical data with a margin of error of 0.05 . The questionnaires were disseminated to 254 two hundred and fifty-four construction personnel; one hundred and thirteen (113) of the two hundred and fifty-four structured questionnaires disseminated were retrieved from the construction personnel which constituted a 55.51 percent response rate. This is above the percent response rate for Nigeria as opined by Takim et al. (2004). The research participants are as indicated in Table 2.

Likert scale was used in the design of the questionnaire on a 7-point extent to allow for a wide range of options for the respondent to be able to choose with no restrain (Cohen, Manion, \& Morrison, 2000 cited in James \& Ostrom, 2011). Seven (7) point Likert scale was chosen over 5 point Likert scale and others because Cohen, Manion, \& Morrison (2000) cited in James \& Ostrom (2011) asserted that data from Likert scale is significantly less accurate as the number of scale points drops below 5 or above 7 . The mean score was employed by lots of strategy researchers (Biggs et al., 2013; Khoshtale, 2016). We analysed the data retrieved using K-mean algorithms for ease of determining and interpreting the clusters coupled with no standard objectives for clusters selection in place yet (Hair et al., 2010), and a one-way ANOVA of the SPSS version 21. The clusters that emerged were cross-checked to know whether there exist differences between them or not to prove that they are of a different cluster.

Table 2. Demographic profile of the firms

\begin{tabular}{llll}
\hline S/N & Construction Personnel & Denotation & No \\
\hline 1. & Project managers & $\mathrm{P}$ & 19 \\
2. & Managers & $\mathrm{M}$ & 15 \\
3. & Senior management & $\mathrm{SM}$ & 32 \\
4. & Supervisors & $\mathrm{S}$ & 34 \\
5. & Foremen & $\mathrm{FR}$ & 10 \\
& & & \\
1. & Male Gender & $\mathrm{M}$ & $89.4 \%$ \\
2. & Female & $\mathrm{F}$ & $10.6 \%$ \\
& & & \\
1. & Indigenous firms & & 76.1 \\
2. & Foreign firms & & 23.9 \\
\hline
\end{tabular}

\section{RESULTS AND DISCUSSION}

\subsection{Clustering of All Variables Involved In the Analysis}

Before we introduced the data into the K-mean algorithm the data were first standardised as $\mathrm{z}$ scores (mean $=0$, standard deviation $=1$ ) to do away with intrinsic bias in computing Euclidean distance among the variables (Tan et al., 2012). We formed three clusters using the sample size (113 responses). This was so done for us to align clusters to the typology of the hierarchy culture in Cameron and Quinn (2011) model which can be high, low, and moderate (Elangovan \& Jayashree, 2013; SHRM, 2020). There were altogether 66 construction firms in cluster one, 17 in cluster two, and 30 in cluster three. We carried out a meaningful comparison with the 
entire sample using (SPSS) in identifying the best/strong organisational culture among the groups.

\subsection{Organisational Culture Characterisation}

Organisational culture characterisation of construction firms in Nigeria was determined using a one-way ANOVA and K-mean analysis. We merged the result of the one-way ANOVA with the K-mean result as seen in Table 4a, 4b, and 4c. From Table 4 three distinct clusters emerge; moderate organisational culture, weak organisational culture, and strong organisational culture which cut across indigenous, foreign construction firms.

\subsubsection{Cluster One}

The first cluster consisted of 66 construction firms (Table 3). From table 4a, Although the companies seem to have structured organisational culture on the ground, their organisational culture pays no attention to their diversity right from the recruitment level, their ability to recruit a diverse workforce is left to chance or perhaps too purely competency $(-0.01881)$, the recruitment of workers not based on cultural diversity (Race, ethnicity, gender, age, and disability) (-0.09212, $-0.18842,-0.28634,-0.22768$, and 0.02691). Such firms have a low potency of recruiting a diverse workforce that would be of great benefit to the company. Also by not employing based on diversities, the organisations did not have a diversity and/ or equal opportunities policy in place (0.07871) at least not such as being documented.

As such managers have negative or no approaches and access to cases of diversity (-0.02292) coupled with the fact that management has no differing/diverse perspectives when solving problems (-0.01182) which connote that they do not embrace contingency approach in their management application. Invariably the supervisor commitment and supports to diversity are low (0.15616). The effect is that workers' unique attributes, traits, characteristics, skills, experience, and background are sparingly (0.00928) valued at work. The poor leadership and communication generated a low response of positive attention to the employees' values displays as $0.04208,0.1248,0.09485,0.08007,0.18673,0.2511$, and 0.26055 respectively. This connotes that there is no balance between the organisational values and the employees' values which pictures a frenzied atmosphere. The analysis of the teamwork variables in this cluster in table $4 \mathrm{~b}$ discloses a negative work attitude within the teamwork; there is a lack of collaboration (-0.09926), suspicious of others (0.21582) which hinders teamwork and involvement of all participants in planning (-0.10013) cohesiveness and knowledge sharing because of withholding of information from each other (0.27596), there is the ripple effect of participants blaming one another when things went wrong (0.03581) and lack of loyalty, no motivation and responsibility to best practices among the workers (-0.12945).

In Table 4c the organisational culture gives birth to diversity management that is more or less weak or not existing evidence by lack of top management's personnel intervention $(-0.26374)$, low attention to work and family policies $(0.03945)$, lack of informal mentoring (-0.00144), no inclusion of diversity in management succession planning (-.03165), lack of Internal audit or attitude survey (-.01838), Diversity training programmes is little considered as a part of organisation strategy (.07244). The organisations in cluster one display poor performance outcome as regards their employees' retention (-0.2346), productivity $(-0.19067)$, work quality (-0.1437), creativity /innovations (-0.06602), workgroup communication (-0.07115), but little improvement in problem-solving (0.00177) and poor overall firm performance as -0.00733 . This poor outcome boils down to the weak strength of their organisational culture in effecting diversity management that would drive better organisational performance. This result agrees with Hitt et al. (2010) who observes that organisational culture is the social energy that drives the organisation to success or failure. 


\subsubsection{Cluster Two}

The organisation in this cluster is made up of 17 cases (Table 3). No mission statement that encapsulates their core values is put in place. In Table 4a the organisations in this cluster employ not based on diverse people (-1.00472); this connotes firms do not formally key into the employment of diverse people for business benefits. This is evidenced by the low recruitment of workers based on demographic diversity equally known as surface diversity (Race, ethnicity, gender, age, and disability) $(0.17864,0.55495,0.56423,0.27615$, and -0.16204$)$ respectively. Also, there is no diversity and/ or equal opportunities policy in place (-1.12463), as such managers have no approaches and accessible to handle cases of diversity (-0.92095) coupled with the fact that there are no management differing/diverse perspectives when solving problems (-1.23846); this shows the absence contingency theory in their management application. Invariably there is no supervisor commitment and supports to diversity (-1.70683). The effect of this is that workers' unique attributes, traits, characteristics, skills, experience, and background (-1.21408) are not valued at work.

There is no positive retort to the employees' values displays as $-0.85986,-0.6111,-1.13705$, $1.15058,-0.71593,-0.03829$ and -0.19621 respectively. Since the employees' values do not align with the organisations' values a clear picture of dissatisfaction is portray which may lead to low worker retention and bad work outcome. In table $4 \mathrm{~b}$ the analysis of the teamwork variables in this cluster discloses a negative work attitude within the teamwork; there is a lack of collaboration (-0.39286), low suspicious of others (0.0604) which hinders teamwork, and not involvement of all participants in planning (-0.71052) cohesiveness and knowledge sharing because of withholding of information from each other (0.21045), there is also a low scenario of participants blaming one another when things went wrong (0.28111) and lack of loyalty, motivation and responsibility to best practices among the workers $(-0.45929)$.

The poor organisational culture could only drive diversity management that is more or less weak or not existing evidence by lack of top management's personnel intervention (-0.14061), no attention to work and family policies $(-1.22402)$, lack of informal mentoring $(-0.71914)$, lack of inclusion of diversity in management succession planning (-.98235), no internal audit or attitude survey (-.83246), Diversity training programs is not considered as a part of organisation strategy (-1.13907). The organisations in this cluster display poor performance outcomes as regards their employees' retention -0.60901$)$, productivity $(-0.42129)$, work quality $(-0.49083)$, creativity /innovations (-0.85619), workgroup communication (-0.80835), Problem-solving ($0.88836)$, and overall firm performance as (-0.83949). This poor outcome boils down to the weak strength of their organisational culture in effecting diversity management that would drive better organisational performance.

\subsubsection{Cluster Three}

The organisation in this cluster is made up of 30 cases (Table 3) From Table 4a organisations in cluster three employs people based on cultural diversity (0.62985); this implies they leverage their diversity for commercial benefits evidenced by the uneven spread of cultural diversity within the workforce (Race, ethnicity, gender, age, and disability) $(0.09529,0.10315,0.29114$, 0.32923 , and 0.03532 ) respectively. The firms have diversity and/ or equal opportunities policy in place (0.47199), as such managers have positive approaches and accessibility to diversity (0.57077) coupled with the fact that they possess management differing/diverse perspectives when solving problems $(0.68533)$ which connotes that they embrace contingency approach to management.

This invariably encourages their supervisor in their commitment and supports diversity (0.51508). The effect is that workers' unique attributes, traits, characteristics, skill s, experience, and background (0.66786) are valued at work. There is positive attention to the 
employees' values displays as $0.36881,0.0785,0.44199,0.47851,0.0011,-0.5657$ and -0.4668 respectively. Table $4 \mathrm{~b}$ discloses a good work attitude within the teamwork; there is a collaboration (0.43768), no suspicious of others (-0.509) which encourages teamwork and involves all participants in planning (0.6229), cohesiveness and knowledge sharing because of not withholding of information from each other (-0.7264), Also members blames no one when things went wrong (-0.2463) and loyalty, motivation and responsibility to best practices among the workers $(0.54505)$. Table $4 \mathrm{c}$ displays their profound diversity management evidence by top management's personnel intervention (0.65992), attention to work and family policies (0.60682), encourages informal mentoring (0.40004), the inclusion of diversity in management succession planning (.62419), internal audit or attitude survey (.50048), diversity training programs are considered as a part of organisation strategy (.44814).

The organisations in cluster three displays good performance outcome as regards their employees' retention (0.89093), productivity (0.6455), work quality (0.59428), creativity /innovations (0.63042), workgroup communication (0.61459), problem-solving (0.49957), and overall firm performance as (0.49183). This good outcome flows from their organisational culture potency in effecting diversity management that would drive better organisational performance. This is in line with Hitt et al. (2010); Olsen and Martins (2012) and Nikpour (2017) who asserted that having strong organisational culture contents is inevitably a good driver of diversity management for a better organisational performance realisation.

Table 3. Distance between final cluster centres

\begin{tabular}{llll}
\hline Cluster & 1 & 2 & 3 \\
\hline 1 & & 9.186 & 5.929 \\
2 & 9.186 & & 13.167 \\
3 & 5.929 & 13.167 & \\
\hline
\end{tabular}

\subsection{Enumeration of Factors That Contribute to the Organisational Culture Capability}

The factors that contribute to the organisational culture capability were obtained from the contributions of all the variables in the cluster. We used the effect size as a measure and selection of the factors that contribute the highest to the organisational culture capability. In Table $4 \mathrm{a}, 4 \mathrm{~b}$, and $4 \mathrm{c}$, the highest variables that contribute the highest effect size $(\mathrm{F})$ are 53.613, which is "my supervisor is committed to, and support diversity", followed by 40.777, "I have sufficient support to developing skills and progress my career" (employees' value), 38.662 "managers advocates that education about diversity will enhance the company's performance" (education on diversity). The next is followed by "managers sought different perspectives when solving problems" (contingency approach), 29.525, followed by "work and family policy are given adequate attention", 26.719, contributed most to the cluster solution. These also provided the greatest separation between clusters.

\subsection{Managerial Implication on the Outcome of the Cluster Analysis and Their Influencing Strength}

The results presented in Table $4 \mathrm{a}, 4 \mathrm{~b}$, and $4 \mathrm{c}$ shows that there were significant differences in the performance among the clusters based on the outcomes of the one-way ANOVA test. This study looked closely to discover the difference among the clusters as regards the impact of organisational culture, teamwork, cultural diversity, diversity management, on organisational performance, as well as whether organisational culture, diversity management contributed to the differences in performance. 
For the construct of the cluster one-way ANOVA was employed through all the clusters for all the constructs using the Bonferroni method. By this method, the test of significant differences on the impact of the clusters was achieved. The outcome of the test revealed a large statistical significant $(\mathrm{p}<0.05)$ difference among the constructs except for race, culture/tradition, beliefs, targeted recruitment of managers, key outside hires which showed a non-significant difference.

Applying the mean comparison, the organisations in cluster three outperformed those in cluster one and cluster two because it has a higher mean compare to other clusters. Most of the mean in cluster three exhibited a positive mean value than the other clusters. Cluster three appeared to be the organisations with the best organisational culture than the other two clusters. Cluster two has a higher mean than cluster one. Cluster one although not the best of the cluster, gives little attention to family and work policy. However, the factors that would have fostered a better team diversity and teamwork such as commitment, best practice, collaboration, free communication, loyalty are lacking resulting in low performance. This is in agreement with Ankrah (2007) who stated that there is a loose end in terms of collaboration among the workgroup within construction organisations, and Loosemore et al. (2012) also stressed the importance of a wellstructured management approach to tighten the loose end to avoid the poor performance.

Cluster two has a weak organisational culture, despite this, their employees are valued. However, there is a high manifestation of social identity negative outcome among them compared with cluster one and cluster three. This is a situation many of the theorists such as Loosemore et al. (2012), Olsen and Martins (2012) opined can be avoided with effective diversity management in place.

The third cluster can be said to be an ideal cluster for construction firms to emulate because of the positive outcome as a result of the underlying factors the managers were able to put in place for the benefit of the firms. Organisations in cluster three started their diversity management right from the recruitment entry point. A wide range of diversities was absorbed into the organisations compared to other clusters which reflect in their teamwork. Comparing each cluster diversity management approach, cluster three provided wider management interventions in terms of various diversity management in place compared to cluster one and cluster two. This is in line with the proposition of Olsen and Martins (2012) that organisations adopting the dual integration diversity management approach have a broader pool of management tools to choose from depending on the situation at hand.

From Table 3, cluster one and three are different, cluster two is a bit close to cluster three. This signifies that construction organisations exhibit different organisational culture.

The number of cases allocated to cluster one is 66 ; cluster two is 17 , while cluster three which are the organisations that have strong organisational culture is allotted 30 cases (Table 5). This entails that there is a distinct culture within the clusters.

Table 5. Cases in the cluster

\begin{tabular}{lcl}
\hline Number of Cases in each Cluster \\
\hline \multirow{3}{*}{ Cluster } & 1 & 66.000 \\
& 2 & 17.000 \\
Valid & 3 & 30.000 \\
Missing & \multicolumn{2}{c}{113.000} \\
\end{tabular}




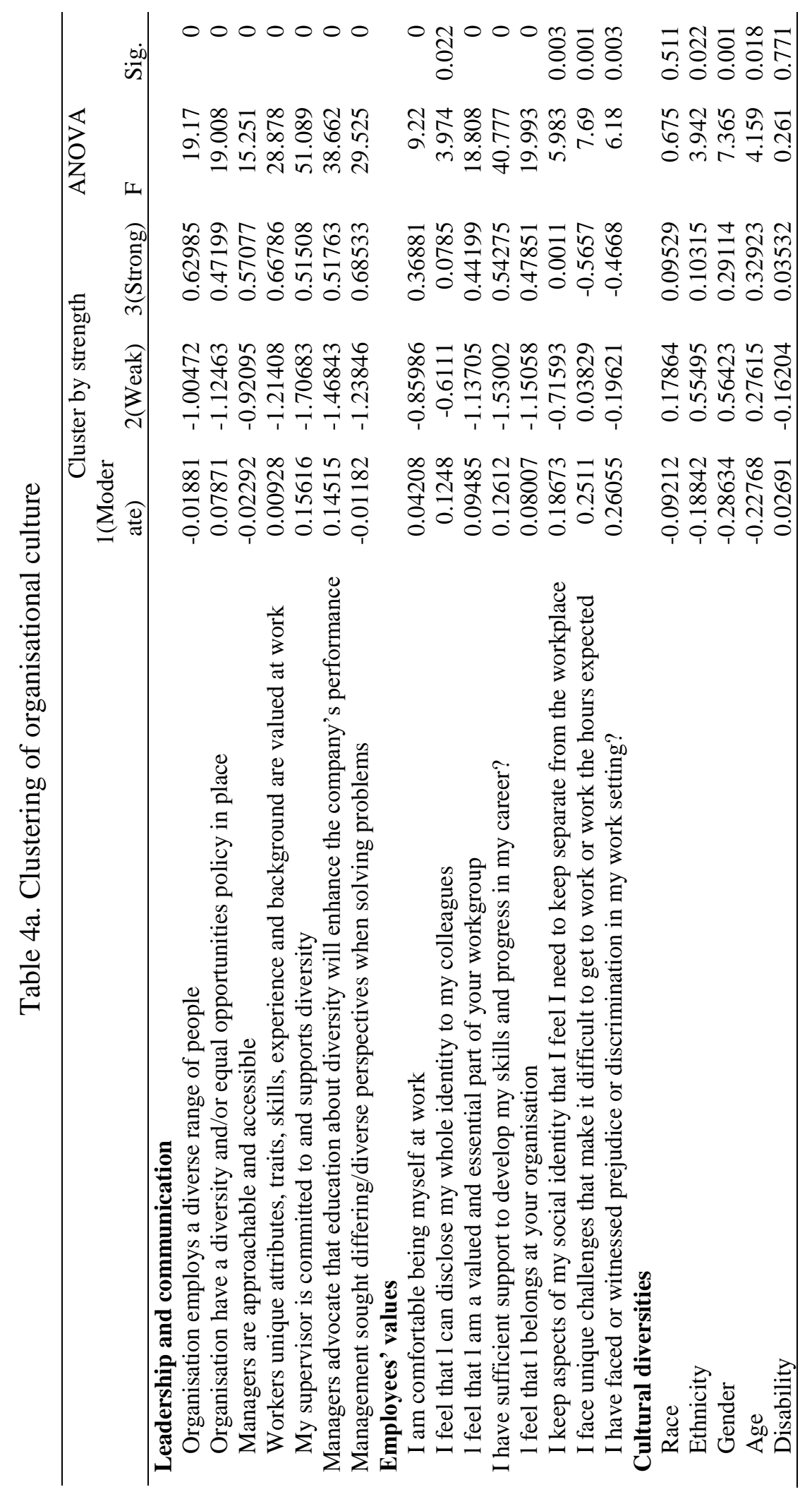




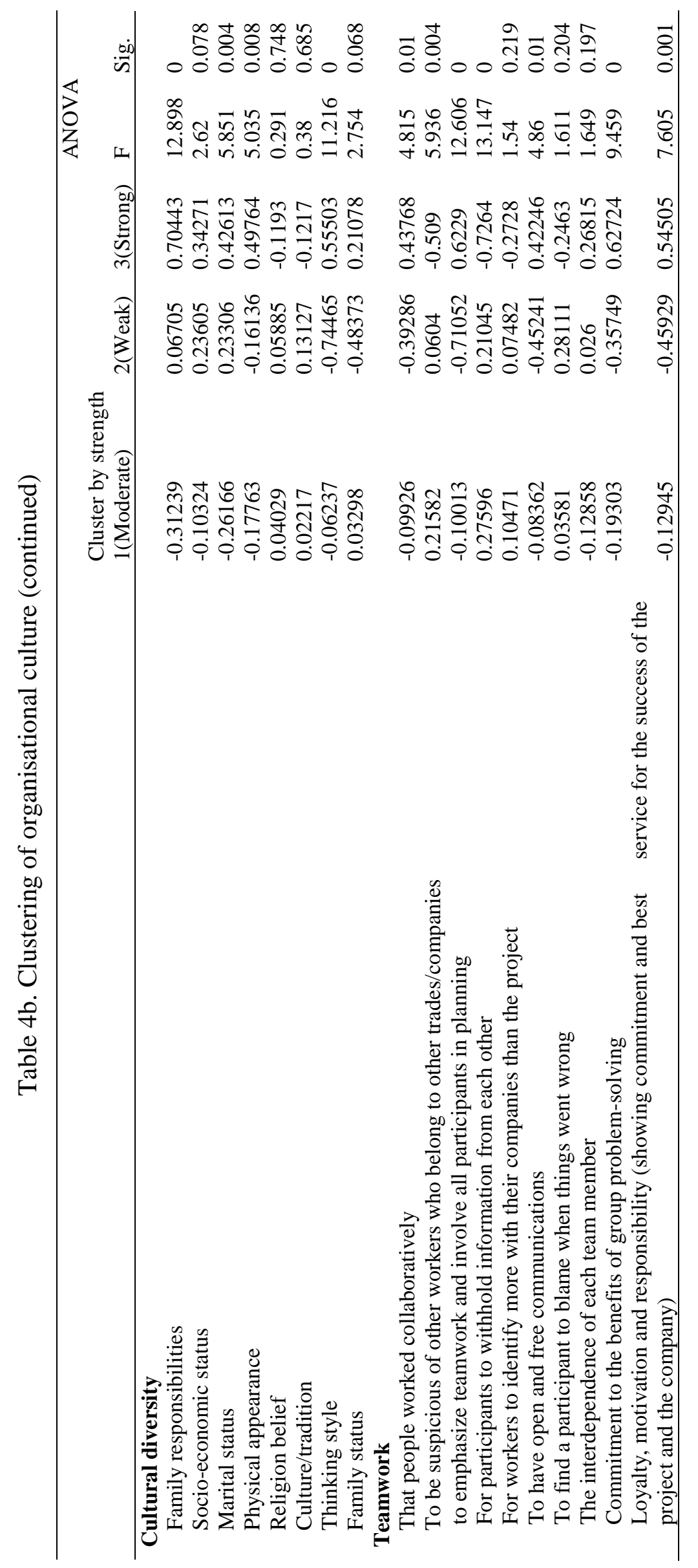




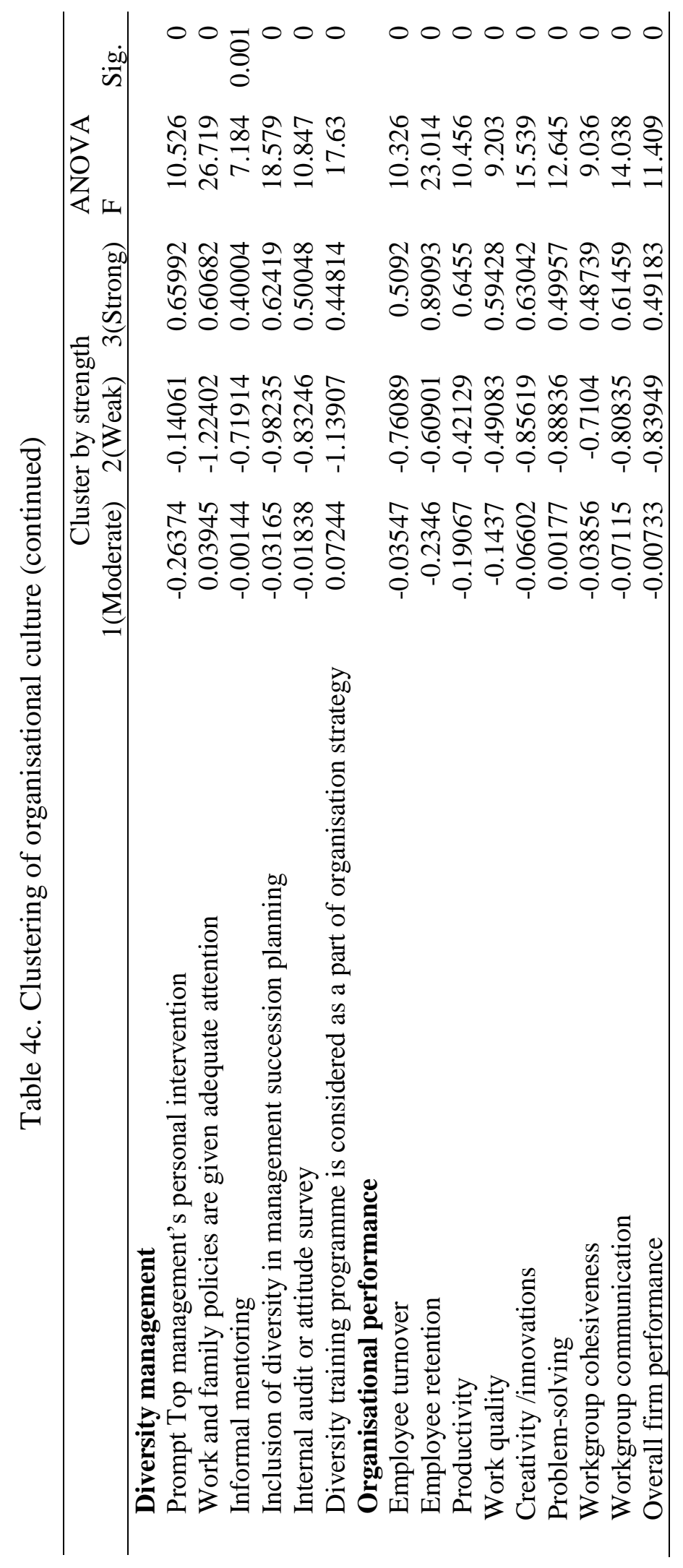




\section{CONCLUSION AND RECOMMENDATION}

Considering the myriads of challenges facing the construction industry, the existence of weak organisational culture (66 cases) in the construction firms in Nigeria indicates that a high percentage of construction firms in Nigeria cannot leverage their diversities through their organisational culture that implement and make diversity management culture throughout for a good organisational performance. Little wonder the poor performance observed by previous researchers and thus is a pointer for every construction firm that wants to excel in this twentyfirst century to put in place a wider range of diversity management style that addresses the cultural diversity of the workforce. Also, it is of note that supervisors' commitment and support for diversity, and skills development, and career progression is the most key driver of diverse workforce impact on the organisational culture. The construction firms should, therefore, improve on their organisational culture as well as pay attention to all the features that make cluster three an ideal organisational culture. And thus, we recommended that:

1. Construction firms should provide a wider management intervention in terms of diversity management in place to curb the negative effect of cultural diversity within the teamwork and by large among the workforce.

2. Every member of the workforce should be made aware of the cultural diversity and culture of the company at an early state especially at the recruitment entry point.

3. Motivate supervisors to be committed to and support diversity

4. A family and work policy should be instituted as part of organisational policy.

This study has contributed to the body of knowledge in the area of organisational culture characterisation of construction firms in Nigeria. The incoming researcher should do a comparative study on the organisational culture of the different construction firms as it relates to their construction business sustainability.

\section{REFERENCES}

Agboola, M. (2011). Impact of Organisational Culture on Performances of Universities [Covenant University].

http://eprints.covenantuniversity.edu.ng/459/1/Impact_of_organisational_culture_on_the_performa nces_of_universities_in_Nigeria.pdf

Akinyemi, A. P., Dare, G. M., Anthony, A. I., \& Dabara, D. I. (2016). Building Collapse in Nigeria: Issues and Challenges Building Collapse in Nigeria: Issues and Challenges. Conference of the International Journal of Arts \& Sciences, 9(1), 99-108.

Angela, L., Liou, S., Miron-Spektor, E., Koh, B., Chan, D., Eisenberg, R., Schneider, I.K. (2017). Middle Ground Approach to Paradox: Within- and Between-Culture Examination of the Creative Benefits of Paradoxical Frames. Journal of Personality and Social Psychology 114(3), 1-74

Ankrah, N. . (2007). An Investigation into the Impact of Culture on Construction Project Performance [University of Wolverhampton]. https://core.ac.uk/download/pdf/1931942.pdf

Bartlett, J., Kotrlik, J. \& Higgins, C. (2001). Organisational Research: Determining Appropriate Sample Size in Survey Research. Information Technology, Learning, and Performance Journal, 19(1), 6

Biggs, S. E., Banks, T. D., Davey, J. D., \& Freeman, J. E. (2013). Safety leaders' perceptions of safety culture in a large Australasian construction organisation. Safety Science, 52, 3-12. https://doi.org/10.1016/j.ssci.2012.04.012

Brett, J., Behfar, K., \& Kern, M. C. (2006). Managing multicultural teams. Harvard Business Review, 84(11). https://doi.org/10.4324/9781315881201-17

Cameron, K. S., \& Quinn, R. E. (2011). An Introduction to changing organisational culture: Based on the competing values framework. In Diagnosing and chaning organisational culture. Jossey-Bass.

Chartered Management Institute. (2015). Understanding Organisational Culture. https://www.managers.org.uk/ /media/Files/PDF/Checklists/CHK-232-Understandingorganisational-culture.pdf

David P, Bloom M. and Hillman J. (2007). Investor Activism, Managerial Responsiveness Corporate 
Social performance. Strategy Management Journal vol 28 (1), 91-100.

Elangovan, A., \& Jayashree, J. . (2013). A study on organisational culture with Reference to Sail, Salem. International Journal of Social Science \& Interdisciplinary Research, 2(6).

Enyioko, N. (2017) Ethical Characterisation of Entrepreneurs and Their Organisational Growth in Nigeria. Available at SSRN: https://ssrn.com/abstract=2908030 or http://dx.doi.org/10.2139/ssrn.2908030

Flyvbjerg, B. (2006). Five misunderstandings about case-study research. Qualitative Inquiry, 12(2), 219-245. https://doi.org/10.1177/1077800405284363

Gibson, J. L., Ivancevich, J. M., Donelly Jr, J. H., \& Konopaske, R. (2012). Organizations Behaviour, Structure, Processes. In The McGrawHill companies.

Hair, J. F., Black, W. C., Babin, B. J., \& Anderson, R. E. (2010). Multivariate Data Analysis. In Vectors. https://doi.org/10.1016/j.ijpharm.2011.02.019

High performing systems Inc. (2009). TeamWork Questionnaire ${ }^{\mathrm{TM}}$ Feedback Report For Sample. Teamhttps://hpsys.com/PDFs/TWQSampleReport.pdf Accessed 12/8/2020

Hitt, M. A., Ireland, R. D., \& Hoskisson, R. E. (2010). Strategic Framework for Teacher Education And Professional Development United States Agency for International Development. In Strategic Management - Competitiveness and Globalization.

Hofstede, G. (1993). Cultures and Organizations - Software of the Mind: Intercultural Cooperation and Its Importance for Survival. Administrative Science Quarterly, 38(1).

Hogan, S. J., \& Coote, L. V. (2014). Organizational culture, innovation, and performance: A test of Schein's model. Journal of Business Research, 67(8), 1609-1621. https://doi.org/10.1016/j.jbusres.2013.09.007

Horwitz, S. K. (2005). The Compositional Impact of Team Diversity on Performance: Theoretical Considerations. Human Resource Development Review, 4(2), 219-245. https://doi.org/10.1177/1534484305275847

James, T. Ostrom, C.L. (2011). Using Likert-Type Scales in the Social. Journal of Adult Education, 40

Kreitner, R., and Kinichi, .A. (2004). Organizational Behaviour, Boston: McGraw-H (1), 19-22

Khoshtale, O. (2016). The relationship between team effectiveness factors and project performance aspects : A case study in Iranian construction project teams. International Journal of Humanities and Cultural Studies, Special Ma(2016), 1738-1767.

Loosemore, M., Phua, F., Teo, M., \& Dunn, K. M. (2012). Management strategies to harness cultural diversity on Australian construction sites - A social identity perspective. Australasian Journal of Construction Economics and Building, 12(1), 1-11. https://doi.org/10.5130/ajceb.v12i1.2433

Maseko, T. S. B. (2017). Strong vs. Weak Organizational Culture: Assessing the Impact on Employee Motivation. Arabian Journal of Business and Management Review Manag Review, 7(1), 1-5.

McShane, S. L., \& Steen, S. (2015). Chapter 1 Introduction to the Field of Organizational Behaviour. Canadian Organizational Behaviour, 9th ed, 1-25. http://libguides.royalroads.ca/fair_dealing.

Nikpour, A. (2017). The impact of organizational culture on organizational performance: The mediating role of employee's organizational commitment. International Journal of Organisational Leadership, 6, 65-72.

Ofori, G. (2015). Nature of the Construction Industry, Its Needs and Its Development: A Review of Four Decades of Research. Journal of Construction in Developing Countries, 20(2), 115-135

Olsen, J. E., \& Martins, L. L. (2012). Understanding organizational diversity management programs: A theoretical framework and directions for future research. Journal of Organizational Behavior, 33(8), 1168-1187. https://doi.org/10.1002/job.1792

Oyewobi, L. O. (2014). Modelling Performance Differentials in Large Construction Organisations in South Africa [University of Cape Town]. https://open.uct.ac.za/bitstream/handle/11427/12939/thesis_ebe_2014_oyewobi_lo.pdf?sequence= $1 \&$ isAllowed $=\mathrm{y}$

Preeti, B., Poonam, 1. \& Ekanshi, G. (2014). Workforce Diversity Management: Biggest Challenge or Opportunity for 21st Century Organisations. IOSR Journal of Business and Management, 16, 102107

Rijamampianina, R and Carmichael, T. (2005). A Pragmatic and Holistic Approachto Managing Diversity. Problems and Perspectives in Management, 3(1)

Sanz-Valle, R., Naranjo-Valencia, J. C., Jiménez-Jiménez, D., \& Perez-Caballero, L. (2011). Linking 
organizational learning with technical innovation and organizational culture. Journal of Knowledge Management, 15(6), 997-1015. https://doi.org/10.1108/13673271111179334

Saxena, A. (2014). Workforce Diversity: A Key to Improve Productivity. Procedia Economics and Finance, 11, 76-85. https://doi.org/10.1016/s2212-5671(14)00178-6

Schwartz, S. H. (2012). An Overview of the Schwartz Theory of Basic Values. Online Readings in Psychology and Culture, 2(1), https://doi.org/10.9707/2307-0919.1116 Accessed 16/09/2017. $17: 51$

Sezerel, H \& Tonus, H.Z. (2016). Effects of the organizational culture on diversity management perceptions in hotel industry. Journal of Human Resource Management, xix, 1-7

Sheridan, E. J. (1992). Organizational culture and employee retention. Academy of management journal 1992. Vol. 35, No. 5, 1036-1056.

Shore, B., \& Cross, B. J. (2005). Exploring the role of national culture in the management of large-scale international science projects. International Journal of Project Management, 23(1), 55-64. https://doi.org/10.1016/j.ijproman.2004.05.009

SHRM. (2020). Understanding and developing organizational culture. https://www.shrm.org/resourcesandtools/tools-andsamples/toolkits/pages/understandinganddevelopingorganizationalculture.aspx

Sorge, A., \& Hofstede, G. (1983). Culture's Consequences: International Differences in Work-Related Values. Administrative Science Quarterly, 28(4), 625. https://doi.org/10.2307/2393017

Syed, J., \& Kramar, R. (2009). Socially responsible diversity management. Journal of Management and Organization, 15(5), 639-651. https://doi.org/10.5172/jmo.15.5.639

Takim, R., Akintoye, A., \& Kelly, J. (2004). Analysis of Performance Measurement in the Malaysian Construction Industry. In S. O. Ogunlana, C. Chareonngam, P. Herabet, \& B. H. W. Hadikusumo (Eds.), Proceeding of Globalization and Construction (pp. 533-546). AIT Conference Centre.

Tan, Y., Shen, L., \& Langston, C. (2012). Competition Environment, Strategy, and Performance in the Hong Kong Construction Industry. Journal of Construction Engineering and Management, 138(3), 352-360. https://doi.org/10.1061/(asce)co.1943-7862.0000407

Teräväinen, V., Junnonen, J. M., \& Ali-Löytty, S. (2018). Organizational culture: Case of the finnish construction industry. Construction Economics and Building, 18(1), 48-69. https://doi.org/10.5130/AJCEB.v18i1.5770

Waiganjo W, \& Mukulu, E \& Kahiri J, (2012). "Relationship between Strategic Human Resource Management and Firm Performance of Kenya's Corporate Organizations". International Journal Of Humanities And Social Science, Vol 2, No. 10, pp 62-70 